\title{
Research on the Implementation Path of Rural Land Ownership Management in Yunnan Ethnic Areas Against the Background of "Three Rights Separation"*
}

\author{
Jing Wang \\ School of Economics and Management \\ Yunnan Agricultural University \\ Kunming, China 650201
}

\author{
Rui Chen \\ School of Economics and Management \\ Yunnan Agricultural University \\ Kunming, China 650201
}

\author{
Wei Long** \\ School of Economics and Management \\ Yunnan Agricultural University \\ Kunming, China 650201 \\ **Corresponding Author
}

\begin{abstract}
In the reform of rural land property right system in Yunnan Province, there are some problems, such as insufficient scale of land circulation, inadequate management function of the right subject, complex contradictions and disputes of land ownership, lack of diversified operation subject and insufficient financial supporting mechanism. This paper selects the typical national villages in Yunnan Province, adopts the methods of literature, focus group and in-depth interview, through the investigation of the existing problems, analyzes the reasons that affect the operation efficiency of rural land system in ethnic areas, and puts forward the logical framework and countermeasures to solve the problems combined with the particularity of ethnic areas. It provides a path choice for promoting the implementation of the policy of "Three Rights Separation" in Yunnan ethnic areas.
\end{abstract} path

Keywords-ownership system; ethnic areas; implementation

\section{INTRODUCTION}

Land ownership system provides a legal and normative framework for agricultural production and economic activities, which is of great significance to the effectiveness of rural social and economic activities. When determining the rights of ownership owners, they encourage people to use land in a sustainable way or invest in resource protection, whether for individuals or individual organizations.

At present, the relationship between land ownership and land use in China is mostly focused on how to improve agricultural production. However, land ownership not only determines the right of land use, but also the key to obtain

*Fund: This paper is funded by School-level Youth Social Science Fund of Yunnan Agricultural University. natural and environmental resources, soil protection, water resources and wildlife management.

The reform of the "Three Rights Separation" of rural land is an important breakthrough and innovation in the theory of China's rural land system. Classical Marxist writers and mainstream scholars believe that China can realize agricultural modernization through the way of scale and industrialization. Speeding up the reform of "three rights separation" of rural land, encouraging and promoting land circulation and concentration, cultivating new subjects and forming large-scale operation can deepen rural reform, stimulate rural development vitality and provide basic institutional support for rural development.

Yunnan Province is located in the southwest border of China, with a large number of national minorities and remarkable geographical characteristics, which has the particularity of "nation, frontier, mountainous area and poverty". Yunnan has a diverse climate, with a total land area of $383200 \mathrm{~km} 2$, and the cultivated land area in the dam area only accounts for 6\%; According to the statistics of 2016, the per capita arable land area is $0.13 \mathrm{hm} 2$, which is far lower than the world average of $0.32 \mathrm{hm} 2$. With the development of urbanization, a large number of labor force transferred to the city, the phenomenon of abandoned farmland and abandoned land is becoming more and more prominent. Since the implementation of the policy of "separation of three rights", the development of Yunnan Province has lagged behind because of its own particularity and limitations, but the implementation of the separation of three rights has still had a certain positive impact on the scale and industrialization of agriculture in Yunnan Province. Based on the practice of Yunnan, it is necessary to actively explore the implementation 
circulation, but also leads to the diversification of civil disputes in national minority areas.

In most of these different dispute resolution mechanisms, the parties will choose the non litigation dispute resolution mechanism, because the traditional customary law norms have higher efficiency and lower economic cost in dispute resolution, while the national laws usually appear more rigid and inflexible in dealing with disputes.

\section{PROBLEMS IN LAND OWNERSHIP MANAGEMENT IN YUNNAN ETHNIC AREAS}

\section{A. The Supervision and Management Function of Collective Ownership Is Difficult to Play}

In China, the Constitution stipulates that "urban land belongs to the state and rural land belongs to the collective". Collective organization refers to the collective economic organization of a village. However, in the investigation of typical ethnic areas, due to the low level of education and lack of natural resources, most villages are not able to develop and strengthen the collective economy of a village, so the collective economic organization does not have an independent entity form. Its functions of land distribution, supervision, use and management are mainly replaced by the villagers' committee Exercise. Thus, farmers generally lack of awareness of collective land ownership. For example, in the transfer of land management rights, most villagers do not have the awareness of registration management in collective organizations, and the rights and obligations of village collective are not reflected. At the same time, it also brings new management problems and ownership disputes. The main body of rural labor is lack of technology, and market awareness and risk prevention awareness are insufficient.

At present, the conflicts and disputes mainly focus on land transfer, land acquisition and demolition compensation. According to the survey and interview data, although the area of the transferred land is growing rapidly, it is mainly the spontaneous transfer of farmers, most of which are only verbal agreements, which are prone to disputes; the transfer time is short, generally 1-3 years, which is not conducive to the stable development of the agricultural industry; The circulation is mostly within the village, with a small number of circulation objects and external circulation, which is not conducive to the effective flow of means of production elements. Because the policy propaganda and explanation are not in place, the misunderstanding of villagers' understanding is an important reason for disputes.

\section{B. No Enough Attention Is Paid to Farmers' Contracting Rights}

In the rural development of Yunnan national minority areas, with the acceleration of urban and rural overall development process, a large number of young and middle-aged rural male labor force is lost, and the characteristics of weak rural labor force begin to appear. The main body of rural labor is lack of technology, market awareness and risk prevention awareness is insufficient. With the continuous development of the economy, the diversification of business subjects promotes the land

\section{The Operation Entity Has Insufficient Security in the Circulation of the Management Right}

Promoting land circulation to promote land use and increase farmers' income is the focus of the reform of "Separation of three rights". By 2017, the proportion of land circulation in the whole country accounted for one third of the contracted land. In the eastern coastal areas, the proportion of land circulation exceeded $1 / 2$, while that in Yunnan was only $19 \%$. The proportion of land circulation was far lower than that in the whole country and coastal areas (see "Fig. 1"). Mainly manifested in farmers' concerns about risks in land transfer; therefore, farmers in some areas prefer extensive management, even abandoning the land, rather than transferring the land management rights.

In addition, because most of the ethnic areas in Yunnan are located in poverty-stricken and remote mountainous areas with small land area, poor traffic conditions, poor agricultural infrastructure implementation and limited industrial development conditions, it is more difficult to introduce circulation enterprises than other areas. In addition, due to the imperfect financial supporting mechanism, the mortgage evaluation professional institutions have not yet formed, and also seriously affect the efficiency of land circulation in minority areas. the lack of power of financial institutions and other problems 
Proportion of land circulation to contracted land

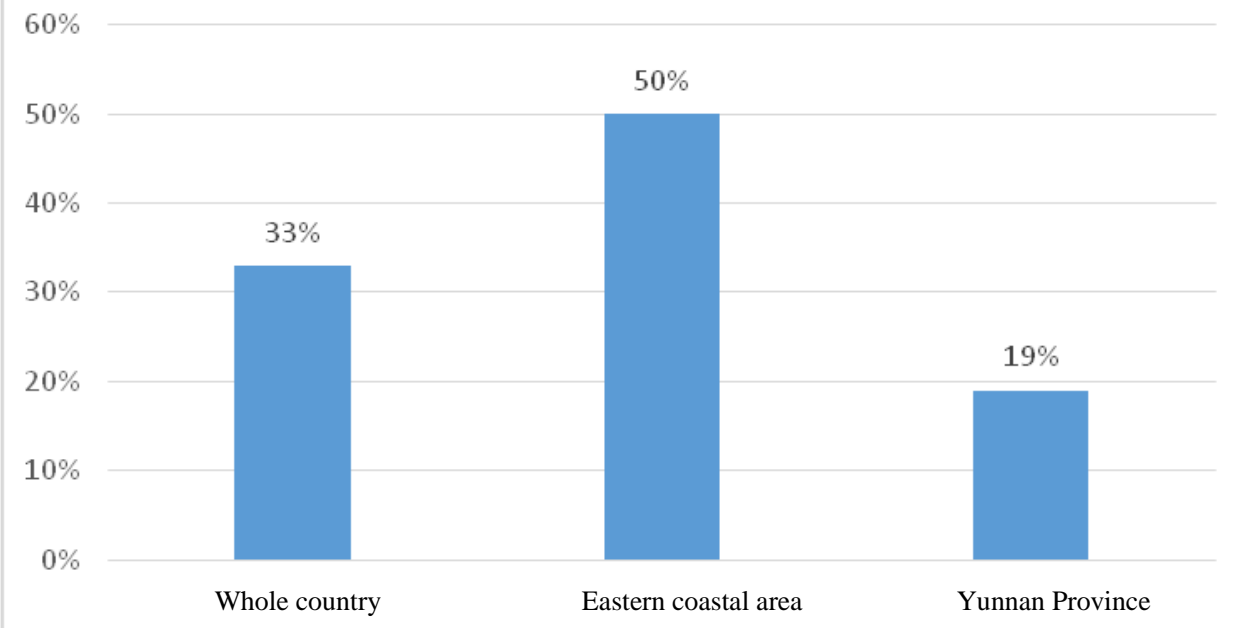

Fig. 1. Proportion of land circulation to contracted land

\section{CONCLUSION AND SUGGESTION}

\section{A. Conclusion}

Land ownership system is an inseparable part of people's cultural and historical development, rooted in national cultural beliefs, rules and practices. The world food and Agriculture Organization defines land ownership as the right to distribute, use, control and transfer land property, as well as related responsibilities and constraints. Therefore, it affects human relations and the interaction between human and land, which can not only be defined economically, but also play an important role in people's social and cultural life.

Land ownership means the way to own land, including legal, emotional and social significance. Land ownership affects the development of a country in many ways. It not only determines the income distribution and land use of local farmers, but also affects social equity, even interwoven with traditional national characteristics. (Dekker 2001, p. 15).

The reform of "Three Rights Separation" of rural land is the need of China's social and economic development. To adjust the structure of land property rights, improve the efficiency of rural land and give consideration to social equity is the goal of the reform of "Three Rights Separation" of agricultural land. Due to the differences of resource endowment, population and production mode, etc., the efficiency of the implementation of the rural land property system is different.

Yunnan has more mountainous land and less land, and the contradiction between people and land is more prominent. The land utilization rate needs to be improved. Due to the lagging development of farming technology and biotechnology, and the low level of land specialization, the productivity of land is not high, leading enterprises are insufficient, social security is lagging behind, and the speed of land transfer is slow. The key to give full play to the positive effect of the "separation of three rights" lies in the reasonable definition of the power scope of the ownership, contract right and management right of rural land. The "separation of three rights" of rural land ownership, contracting right and management right has enriched the diversification of agricultural production entities, broadened financing channels for agricultural production, accelerated land circulation, and will greatly release agricultural productivity. Land mortgages, stock purchases, trusts, etc. are the best ways to achieve the separation of contractual rights and management rights.

Based on the research and analysis of the existing problems in literature and field research, the researcher puts forward the implementation path framework and specific suggestions for the separation of three rights in Yunnan ethnic areas as follows:

The research framework is as shown in "Fig. 2" 


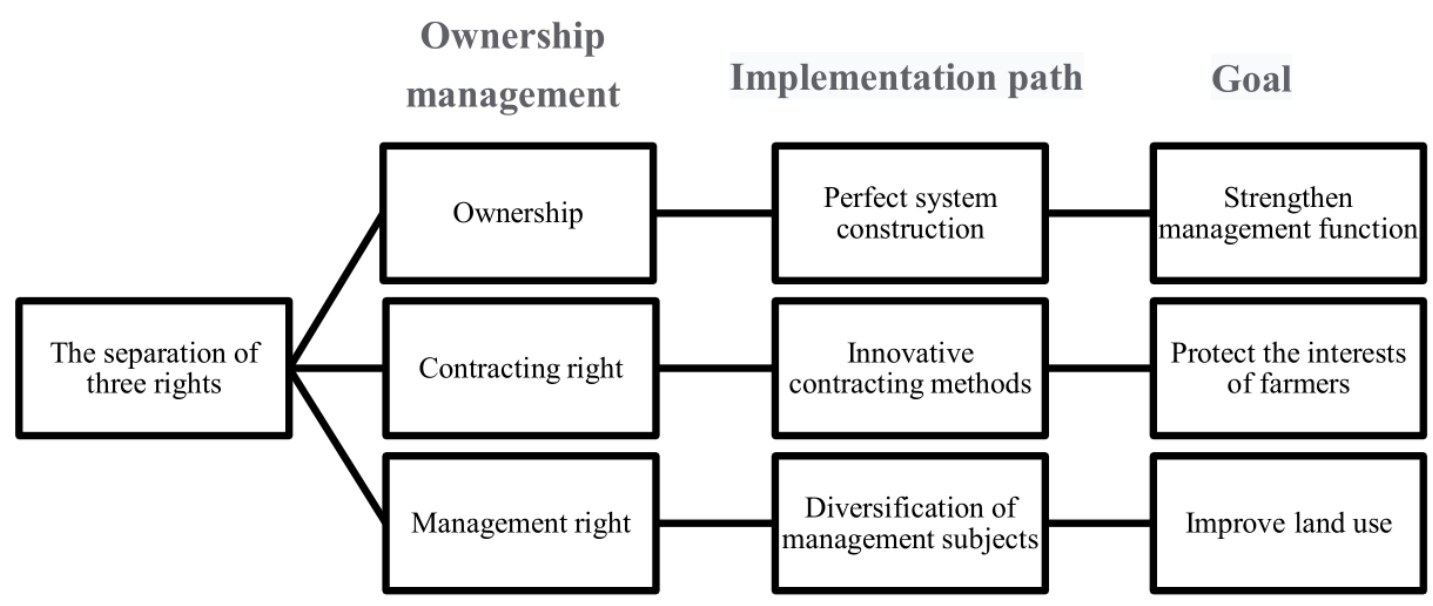

Fig. 2. Implementation path framework.

Due to the special geographical features and national characteristics of Yunnan ethnic areas, the reform of "three rights separation" is difficult to copy the successful experience of other areas. It is necessary to combine the local characteristics, to achieve the supervision and management function of collective ownership based on the improvement of system construction, to innovate the land contract mechanism with the protection of farmers' interests as the core, in order to improve the use of land for the purpose of developing diversified business as the implementation path, to better achieve the goal of "three rights separation" reform in Yunnan.

\section{B. Suggestions}

1) Improving the system construction and guaranteeing the collective ownership

According to the characteristics of national minority areas, it is necessary to establish and perfect the long-term mechanism and dispute settlement mechanism to stabilize and perfect the rural land contract relationship. Gradually formed by the folk consultation, rural mediation, judicial security combined with multi-level rural land contract dispute mediation mechanism. The diversification of disputes inevitably requires a diversified dispute resolution mechanism. In this case, the national legal norms should still play its role, and the new dispute resolution mechanism should also be attached importance to, relying on the advantages of traditional national culture, is conducive to the establishment of a longterm dispute resolution mechanism.

It is required to standardize the land relationship between farmers and rural collectives, to clarify the right boundary of the "village two committees" in land allocation. It is necessary to strengthen the transparency, fairness and openness of the processes of farmland use and distribution adjustment and change, etc., and form a routine supervision mechanism for farmer's right to use collective land. In term of representing, maintaining and enhancing the land rights and interests of the farmers, the rural collective economic organizations should be empowered as much as possible, so as to give full play to the functions of the organization and to strengthen the status of collective ownership.
Dixit's theoretical research on alternative governance in the absence of law shows that the non-standard system can effectively restrain the choice of people's behavior. Therefore, to solve the problem that the normal channel cannot solve, utilize the traditional cultural advantage of the national area, make use of the informal mediation means such as the village rule, and the high-looking old man in the village and so on, so that the problem can be properly solved.

2) Maintaining contracting rights of farmers with innovative contracting systems

The contract right has the mixed right characteristic of the identity right and the property right to the contracted peasant household. In order to encourage the circulation of management right in the "separation of three rights", it should take the protection of farmers' legitimate rights and interests as the basis, respect farmers' choice, open up a new way of circulation to increase income, and guide rather than force the circulation of land. By encouraging the farmers holding the right of land contract to take the right of land management as shares, the income source of farmers will be expanded from the production link of agricultural products to the whole agricultural industry chain. At the same time, the extension of the industrial chain is conducive to creating more jobs, so that farmers can not only share dividends, but also get paid. Through improving the income of farmers' land transfer, increasing the attraction, guiding the transfer of land management rights in Yunnan ethnic areas.

In addition, it is required to promote the reform of the rural social security system, and actively promote the coordinated development of urban and rural areas in medical, education, and employment social security, to untie the security functions of rural land, and improve the efficiency of land agricultural production. Finally, it should change the supplement of the contract right to the rural social security system, and solve the farmers' dependence on land and the pattern of interest distribution.

3) Activating land management rights with diversified operating entities

It is required to improve the basic implementation conditions and moderately develop large-scale operations. It is 
[7] Kang Yongquan. The release of agricultural productivity from the new agricultural land system with separation of powers. Analysis of the role [J]. Henan Social Sciences,2014(10):89-91. necessary to strengthen the implementation of rural roads, bridges, communications, hydropower and other infrastructure in ethnic areas of Yunnan, and integrating resources to establish rural development companies, which can improve the efficiency of rural land transfer transactions, reduce the risk of investment by business subjects, and increase the attractiveness of land transfer. It is required to rely on the advantageous industries of ethnic areas, moderate development, and take the road of green development, which are conducive to giving play to the advantages of ethnic areas and improving the benefits of circulation.

It is required to cultivate new agricultural business subjects based on traditional national characteristics of the industry, to strengthen the local government in policy support, cultivate exemplary family farms, cooperatives and agricultural industrialization consortium. The development mainly focuses on the characteristic agriculture and handicraft industry in the minority areas, and focuses on the deep integration with other industries. According to the resource endowments in the minority areas, the scale of production is managed appropriately, and all kinds of new business subjects with "Internet + " are nurture. Support and encourage new business subjects to industrial parks, science and technology parks, and entrepreneurial parks to develop new industries and new business forms such as agricultural product processing and distribution, e-commerce, and agricultural equipment leasing. Through a series of policies, the growth of new agricultural business subjects in Yunnan's ethnic areas has been promoted.

It is required to improve the mortgage financing mechanism to awaken the "sleeping capital" in rural areas, and solve the bottleneck of rural land financing. At the national level, it necessary to promote a unified evaluation standard system, actively formulate the access mechanism of policyoriented guarantee companies, and promote the financing model of participating in risk control at the local government level. The government leads the establishment of risk mitigation mechanism, can solve the financial institutions' worries, solve the financial institutions' risk tolerance and risk export problems, financial institutions, social capital has motivation and enthusiasm.

\section{REFERENCES}

[1] Ondiege P; 1996. Land Tenure and Soil conservation: In Land we Trust, Iniatives Publishers, Nairobi Kenya.

[2] Zhang Yuning, Tian Donglin.Study on the Utilization of Cultivated Land Resources in Yunnan Based on the Perspective of Separation of Powers[J].Contemporary Economics, 2019(04):92-93.

[3] Dekker, H.A.L. (2001). A New Property Regime in Kyrgyzstan; An Investigation Into Links Between Land Reforms, Food Security, and Economic Development, Universiteit van Amsterdam

[4] Zhang Yuning, Tian Donglin. Research on the Utilization of Cultivated Land Resources in Yunnan from the Perspective of Separation of Powers. Contemporary Economy .2019, (04), 92-93

[5] Tan Lin. Study on the Relationship between Rural Land Circulation and Moderate Scale Management in Yunnan [J]. Contemporary Economy, 2013(13):82-85

[6] Ye Xingqing. From "Separation of Two Rights" to "Separation of Three Powers" - The Past and Future of China's Agricultural Land Property Right System[J]. China Party and Government Cadre Forum, 2014(06): 7-12. 